Cochrane Database of Systematic Reviews

\title{
Interventions for treating intrahepatic cholestasis in people with sickle cell disease (Review)
}

Martí-Carvajal AJ, Martí-Amarista CE

Martí-Carvajal AJ, Martí-Amarista CE.

Interventions for treating intrahepatic cholestasis in people with sickle cell disease.

Cochrane Database of Systematic Reviews 2020, Issue 6. Art. No.: CD010985.

DOI: 10.1002/14651858.CD010985.pub4.

www.cochranelibrary.com 
TABLE OF CONTENTS

HEADER 1

ABSTRACT

PLAIN LANGUAGE SUMMARY

BACKGROUND

OBJECTIVES

METHODS

RESULTS

DISCUSSION

AUTHORS' CONCLUSIONS

ACKNOWLEDGEMENTS

REFERENCES

APPENDICES

WHAT'S NEW

HISTORY

CONTRIBUTIONS OF AUTHORS

DECLARATIONS OF INTEREST

SOURCES OF SUPPORT

DIFFERENCES BETWEEN PROTOCOL AND REVIEW

INDEX TERMS 
[Intervention Review]

\section{Interventions for treating intrahepatic cholestasis in people with sickle cell disease}

Arturo J Martí-Carvajal1,2, Cristina Elena Martí-Amarista3

1Facultad de Ciencias de la Salud Eugenio Espejo, Universidad UTE (Cochrane Ecuador), Quito, Ecuador. 2School of Medicine, Universidad Francisco de Vitoria (Cochrane Madrid), Madrid, Spain. ${ }^{3}$ Department of Family Medicine, Northwell Health Southside Hospital, Bay Shore, New York, USA

Contact address: Arturo J Martí-Carvajal, arturo.marti.carvajal@gmail.com.

Editorial group: Cochrane Cystic Fibrosis and Genetic Disorders Group.

Publication status and date: New search for studies and content updated (no change to conclusions), published in Issue 6, 2020.

Citation: Martí-Carvajal AJ, Martí-Amarista CE. Interventions for treating intrahepatic cholestasis in people with sickle cell disease. Cochrane Database of Systematic Reviews 2020, Issue 6. Art. No.: CD010985. DOI: 10.1002/14651858.CD010985.pub4.

Copyright @ 2020 The Cochrane Collaboration. Published by John Wiley \& Sons, Ltd.

\section{A B S T R A C T}

\section{Background}

Sickle cell disease is the most common hemoglobinopathy occurring worldwide and sickle cell intrahepatic cholestasis is a complication long recognized in this population. Cholestatic liver diseases are characterized by impaired formation or excretion (or both) of bile from the liver. There is a need to assess the clinical benefits and harms of the interventions used to treat intrahepatic cholestasis in people with sickle cell disease. This is an update of a previously published Cochrane Review.

\section{Objectives}

To assess the benefits and harms of the interventions for treating intrahepatic cholestasis in people with sickle cell disease.

\section{Search methods}

We searched the Cystic Fibrosis and Genetic Disorders Group's Haemoglobinopathies Trials Register, which comprises references identified from comprehensive electronic database searches and handsearching of relevant journals and abstract books of conference proceedings. We also searched the LILACS database (1982 to 21 January 2020), the WHO International Clinical Trials Registry Platform Search Portal and ClinicalTrials.gov (21 January 2020).

Date of last search of the Cochrane Cystic Fibrosis and Genetic Disorders Group's Haemoglobinopathies Trials Register: 25 November 2019.

\section{Selection criteria}

We searched for published or unpublished randomised controlled trials.

\section{Data collection and analysis}

Each author intended to independently extract data, assess the risk of bias of the trials by standard Cochrane methodologies and assess the quality of the evidence using the GRADE criteria; however, no trials were included in the review.

\section{Main results}

We did not identify any randomised controlled trials. 


\section{Authors' conclusions}

This updated Cochrane Review did not identify any randomised controlled trials assessing interventions for treating intrahepatic cholestasis in people with sickle cell disease. Randomised controlled trials are needed to establish the optimum treatment for this condition.

\section{PLAIN LANGUAGE SUMMARY}

\section{Interventions for treating intrahepatic cholestasis in people with sickle cell disease}

\section{Review question}

We aimed to review the evidence for treating intrahepatic cholestasis (liver diseases where bile is either not formed or excreted properly (or both)) in people with sickle cell disease. This is an update of a previously published Cochrane Review.

\section{Background}

Sickle cell disease is an inherited condition and the most common hemoglobinopathy occurring worldwide. In 2006, the WHO declared sickle cell disease as a major public health problem with an estimated $70 \%$ of sufferers living in Africa. It is common among people with sub-Saharan African, Indian, Middle Eastern or Mediterranean ancestry.

Sickle cell disease affects the hepatobiliary system (liver, gall bladder, bile ducts), with repeated reduced blood flow and the formation of bilirubin stones (a type of gallstone). This results from sickled cells blocking blood vessels and from a reduction in the lifespan of these cells. Sickle cell intrahepatic cholestasis or sickle cell hepatopathy (abnormal or diseased liver) is one complication of the disease. When diagnosed, people with this condition may show an intense yellowing of skin and eyes due to an increasing level of serum bilirubin (jaundice), tiredness, generalized itching, increasing pain in the upper right quadrant of the abdomen due to gallstones, an enlarged liver and lower hemoglobin levels.

Sickle cell intrahepatic cholestasis, while uncommon, is a potentially fatal complication with a high death rate. There is no agreement in how to diagnose or treat this condition. We wanted to assess the benefits and harms of treatments for intrahepatic cholestasis in people with sickle cell disease.

\section{Search date}

The evidence is current to 25 November 2019.

\section{Study characteristics}

We were not able to find any eligible trials.

\section{Key results}

We were not able to find any eligible trials.

\section{Quality of the evidence}

There is no randomised controlled trial evidence of any intervention for treating intrahepatic cholestasis in people with sickle cell disease. Trials are needed to establish the best treatment for this condition. 


\section{B A C K G R O U N D}

Please refer to the medical glossary (Appendix 1).

\section{Description of the condition}

Sickle cell disease (SCD) is an inherited condition and the most common hemoglobinopathy occurring worldwide (Azar 2017; Piel 2017; Ware 2017). The sickle hemoglobin is an abnormal hemoglobin due to a point mutation of the beta $(\beta)$ globin gene resulting in the substitution of glutamic acid by valine at position 6 of the $\beta$ globin polypeptide chain (Azar 2017; Piel 2017; Ware 2017).

According to the WHO, SCD is a major public health problem (WHO 2006; Modell 2008) with an estimated $70 \%$ of sufferers living in Africa (Tluway 2017). It is common among people with subSaharan African, Indian, Middle Eastern or Mediterranean ancestry (Creary 2007; Modell 2008). The term SCD includes sickle cell anaemia ( $\mathrm{Hb} \mathrm{SS}$ ), hemoglobin $\mathrm{S}$ combined with hemoglobin $\mathrm{C}$ ( $\mathrm{Hb} \mathrm{SC}$ ), hemoglobin $\mathrm{S}$ associated with $\beta$ thalassemia (S $\beta 0$ Thal and $\mathrm{S} \beta^{+} \mathrm{Thal}$ ) and other less prevalent double heterozygous conditions which cause clinical disease (Steinberg 2009; Weatherall 2006). Hemoglobin $S$ combined with normal hemoglobin $(A)$ is known as the sickle cell trait (AS), which is generally asymptomatic and is not part of this review. Recently, the clinical and other aspects of SCD have been reviewed (Azar 2017; Piel 2017; Ware 2017).

Sickle cell intrahepatic cholestasis is a hepatic complication long recognized in people with SCD (Guimarães 2017; Pecker 2018; Theocharidou 2019) and it is considered as an medical emergency (Simon 2016). The cholestatic liver diseases are uncommon conditions characterized by impaired formation or excretion (or both) of bile from the liver. Sickle cell disease affects the hepatobiliary system (Ballas 2012; Ebert 2010), with recurrent ischemia and bilirubin stones resulting from vascular obstruction and red cell hemolysis of the sickle cell (Ballas 2012). Biochemical abnormalities, including elevation of alkaline phosphatases, total bilirubin, and $\gamma$-glutamyl transpeptidase, typically precede the development of jaundice (Carey 2012). Fatigue and pruritus are the most common symptoms associated with cholestasis (Carey 2012). Acute pain in the right upper quadrant is common in people with SCD and described as right upper quadrant syndrome (Ballas 2012). This syndrome must be separated from the more common symptoms of SCD, i.e., hepatic crisis, hepatic sequestration, autoimmune hepatitis, viral hepatitis, hepatic siderosis, sickle cell intrahepatic cholestasis or sickle cell hepatopathy, cholelithiasis, biliary sludge, choledocholithiasis, acute cholecystitis, and chronic cholecystitis (Ballas 2012). Hepatic sequestration is a component of the right upper quadrant syndrome and it is best diagnosed by a rapid enlargement of the liver with a concurrent drop in hemoglobin concentration. Furthermore, the bilirubin will also be elevated, with a high percentage of direct bilirubin (Ballas 2012).

According to a recent expert panel report, people with acute sickle cell intrahepatic cholestasis show a sudden onset of right upper quadrant pain, severe jaundice due to extreme hyperbilirubinemia (both conjugated and unconjugated) usually without urobilinogenuria, a progressively enlarging and exquisitely tender liver and light-colored stools (NIH 2014; Yawn 2014). Furthermore, thrombocytopenia, elevated alkaline phosphatase, variable levels of transaminases, coagulopathy with increased prothrombin time, and partial thromboplastin time to values more than twice baseline values in the absence of accelerated hemolysis or obstruction of the extrahepatic biliary system may also be present.

The clinical picture suggests cholestatic jaundice or choledocholithiasis but without evidence of common duct obstruction or cholangitis. Sickle cell intrahepatic cholestasis is an uncommon but potentially fatal complication with a high death rate (Brunetta 2011; Khan 2011). The disease is caused by diffuse sickling within the hepatic sinusoids that ultimately leads to hypoxic hepatic damage and acute hepatic failure (Khan 2011). Liver biopsies of these people show erythrocytosis, erythrophagocytosis, sinusoidal dilatation and hyperplasia in Kupffer cells (Johnson 1985; Omata 1986; Savafi 2006). Furthermore, sickle cell intrahepatic cholestasis is associated with an increased risk of pericardial tamponade (Khurshid 2002), and renal failure (Khan 2011). Older age and underlying hepatic disease have been suggested as poor prognostic factors for sickle cell intrahepatic cholestasis in adults (Costa 2006).

\section{Description of the intervention}

\section{Non-pharmaceutical interventions}

- Simple red blood cell transfusion for increasing oxygen delivery.

- Exchange transfusion. Red cell exchange or erythrocytapheresis is the most frequently recommended intervention for treating intrahepatic cholestasis in people with SCD (Chitturi 2002; Costa 2006; Danielson 2002; Horn 1987; Karunatilake 2009; Likhtshteyn 2019; Maji 2020; Sheehy 1980; Tiftik 2004). In 1980, Sheehy and colleagues pioneered the use of this procedure in SCD (Sheehy 1980). This Cochrane Review will use exchange transfusion as the term for this procedure. In exchange transfusion the patient's red cells are removed and replaced by exogenous normal red cells. The aim is to raise the level of hemoglobin A to between $60 \%$ and $70 \%$ while lowering the level of hemoglobin $\mathrm{S}$ to $30 \%$ and reverse bilirubin levels to normal values (Delis 2006; Donghaile 2013). This procedure can be carried out manually or mechanically (Kleinman 1984).

- Liver transplantation (Gardner 2014; Kwun 2019; Racho 2019).

\section{Pharmaceutical interventions}

Several pharmacological therapies have been used to treat people affected by intrahepatic cholestasis in other clinical settings (Angulo 2000; Azzaroli 2011; Carey 2012; Geenes 2009; Muriel 2008). This Cochrane Review will include interventions for treating cholestasis-associated pruritus: bile acid-binding resins (i.e., cholestyramine, colestipol); rifampin; opiate antagonists (naltrexone and nalmefene); sertraline; dexamethasone; guar gum; and activated charcoal.

\section{How the intervention might work}

\section{Non-pharmaceutical interventions}

- Simple red blood cell transfusion increasing the hemoglobin and hematocrit levels.

- Exchange transfusion prevents the removed sickle cells from participating in new vaso-occlusive events, reduces hemolytic complications, and provides added oxygen carrying capacity while decreasing the blood viscosity (Swerdlow 2006). Red cell exchange also rapidly decreases the rate of hemolysis, which can decrease liver processing of bilirubin, damage to renal tubular cells and the scavenging of nitric oxide by free hemoglobin 
released from sickle cells (Akinsheye 2010; Donghaile 2013; Kato 2007; Morris 2008).

- Liver transplantation is a transient therapy approach; however, it does not resolve the fundamental issue.

\section{Pharmaceutical interventions}

For treating cholestasis-associated pruritus, bile acidbinding resins (i.e., cholestyramine, colestipol), rifampin, opiate antagonists (naltrexone and nalmefene), sertraline, dexamethasone, guar gum and activated charcoal have the ability to bind biliary acids in the gut lumen and block their absorption (Azzaroli 2011; Carey 2012). However, there is potential for these agents to interfere with the absorption of other medications (Carey 2012). Opiate antagonists reduce the increased level of opioidergic tone associated with cholestatic pruritus.

\section{Why it is important to do this review}

While exchange transfusion is used for treating intrahepatic cholestasis in people with SCD, there appears to be no specific evidence supporting this medical approach. Exchange transfusion requires packed red blood cell units which have undergone prestorage leukoreduction in order to prevent febrile non-hemolytic reactions and which are screened for sickle cell traits to avoid transfusing red cells containing hemoglobin S (Sarode 2006). Due to a discrepancy of red cell antigens between AfricanAmericans and Caucasians (majority blood donors), the incidence of alloantibody formation is very high, which makes it difficult to find compatible red cell units, especially for urgent red cell exchange (Sarode 2006). Therefore, this requires a concerted effort between the apheresis unit, the local blood bank, and the central blood supplier (Sarode 2006). Therapeutic apheresis is a relatively safe procedure; however, it is associated with adverse events. These include hypocalcemia due to citrate; increased frequency of bleeding complications and heparin-induced thrombocytopenia associated with heparin anticoagulation; urticarial reactions to the protein-containing replacement fluid; depletion coagulopathy and immunoglobulin depletion; catheter-related trauma; clotting; infection; and bleeding (Kaplan 2012; Lee 2012). Additionally, the benefits and harms of the alternative non-pharmaceutical intervention, liver transplantation, should be assessed in this clinical setting (Baichi 2005; Emre 2000). This is the second update of a previously published Cochrane Review (Martí-Carvajal 2015; Martí-Carvajal 2017).

Furthermore, clinical effectiveness and safety of the pharmacological therapies used to treat intrahepatic cholestasis in other clinical settings should be reviewed in people with SCD affected by this hepatic disorder.

\section{OB JECTIVES}

To assess the clinical benefits and harms of the interventions for treating intrahepatic cholestasis in people with SCD.

\section{METHODS}

\section{Criteria for considering studies for this review}

Types of studies

Randomised controlled trials (RCTs).

\section{Types of participants}

People with SCD, irrespective of age, gender or setting (e.g. hospital or community) with intrahepatic cholestasis.

\section{Types of interventions}

A single or combined treatment regimen (with each treatment classified as non-pharmaceutical or pharmaceutical, as detailed below) compared to either conventional care or another treatment regimen for intrahepatic cholestasis in people with SCD.

We did not apply any limits with respect to the period of follow up.

\section{Non-pharmaceutical interventions}

- Simple red blood cell transfusion

- Exchange transfusion

- Liver transplantation

\section{Pharmaceutical interventions}

- For treating cholestasis-associated pruritus: bile acidbinding resins (i.e., cholestyramine, colestipol); rifampin; opiate antagonists (naltrexone and nalmefene); sertraline; dexamethasone; guar gum; and activated charcoal.

\section{Types of outcome measures}

\section{Primary outcomes}

1. All-cause mortality

2. Lack of improvement (as defined by trial authors)

3. Adverse events
a. serious adverse events
b. non-serious adverse events

We defined serious adverse events according to the International Conference on Harmonisation (ICH) Guidelines (ICH-GCP 1997), as any event that leads to death, is life-threatening, requires hospitalisation or prolongation of existing hospitalisation, or results in persistent or significant disability. All other adverse events have been considered as non-serious.

\section{Secondary outcomes}

1. Quality of life (as measured by the Pediatric Quality of life Inventory (PedsQL ${ }^{\mathrm{TM}}$ ) or Medical Outcomes 36-Item Short-Form Health Survey (SF-36) questionnaire or by any validated scale)

2. Relief of fatigue (as measured by the PedsQL ${ }^{\mathrm{TM}}$ Multidimensional Fatigue Scale or by any validated scale)

3. Platelet count*

* post hoc change - please refer to the section - Differences between protocol and review.

\section{Search methods for identification of studies}

We did not adopt any language or publication restrictions.

\section{Electronic searches}

We identified relevant studies from the Cystic Fibrosis and Genetic Disorders Group's Haemoglobinopathies Trials Register using the terms: (sickle cell OR (haemoglobinopathies AND general)) AND liver. 
The Haemoglobinopathies Trials Register is compiled from electronic searches of the Cochrane Central Register of Controlled Trials (CENTRAL) (updated each new issue of the Cochrane Library) and weekly searches of MEDLINE. Unpublished work is identified by searching the abstract books of five major conferences: the European Haematology Association conference; the American Society of Hematology conference; the British Society for Haematology Annual Scientific Meeting; the Caribbean Public Health Agency Annual Scientific Meeting (formerly the Caribbean Health Research Council Meeting); and the National Sickle Cell Disease Program Annual Meeting. For full details of all searching activities for the register, please see the relevant section of the Cochrane Cystic Fibrosis and Genetic Disorders Group's website.

Date of last search: 25 November 2019.

We also searched in the following databases:

- LILACS (//lilacs.bvsalud.org) (1982 to 21 January 2020);

- Epistemonikos (www.epistemonikos.org) (up to 21 January 2020).

In addition, we searched trial registries via the WHO International Clinical Trials Registry Platform search portal (ICTRP) (apps.who.int/trialsearch/Default.aspx) and ClinicalTrials.gov (www.clinicaltrials.gov) (21 January 2020).

\section{Searching other resources}

We aimed to check the reference lists of all the trials identified by the above methods. However, we did not identify any RCTs.

\section{Data collection and analysis}

We were unable to identify any RCTs eligible for inclusion in this review. Therefore, we could not perform the data analyses that we had planned. If, in the future, trials are identified and included in the review, we will adhere to the protocol described below.

\section{Selection of studies}

Arturo Martí-Carvajal (AMC) and Cristina Martí-Amarista (CMA) will screen the search results for potentially relevant trials and independently assess them for inclusion or exclusion, using a predesigned eligibility form based on the inclusion criteria. We will resolve any disagreements through discussion until we reach a consensus.

\section{Data extraction and management}

For future updates, one author (AMC) will extract data from the included trials using a spreadsheet data extraction form and one author (CMA) will check the data entered.

We will extract the following data:

- eligibility criteria of the trials;

- demographics (age, sex, country);

- hemoglobin genotype: sickle cell anemia (Hb SS); hemoglobin S combined with hemoglobin $\mathrm{C}(\mathrm{Hb} \mathrm{SC})$; hemoglobin S associated with $\beta$ thalassemia ( $S \beta 0$ Thal and $S \beta+$ Thal);

- hepatic biochemistry at time of entry and at end of trial (total, unconjugated and conjugated bilirubin, alkaline phosphatase, alanine aminotransferase, aspartate aminotransferase, gammaglutamyltransferase, albumin, prothrombin time);
- outcome data (all-cause mortality, lack of improvement, adverse events, quality of life, numbers of jaundice, itching, and being tired, liver biopsy);

- intervention data: type and regimens.

We will discuss any discrepancies between the review authors to achieve a final consensus.

We aim to pool outcome data from trials based on the following follow-up periods (zero to one week, over one week to four weeks, over four weeks to 24 weeks and over 24 weeks). If outcome data do not permit such grouping, we shall pool the end-point data. These different time points are arbitrary and based on clinical judgment.

\section{Assessment of risk of bias in included studies}

For future updates, two review authors will independently assess the risk of bias of each included trial using the domain-based evaluation as described in the Cochrane Handbook for Systematic Reviews of Interventions (Higgins 2011). We will discuss any discrepancies in an aim to achieve consensus.

We will assess the following domains, as per the definitions of each classification below (Higgins 2011).

\section{Generation of allocation sequence (checking for possible selection bias)}

We will describe the method used to generate the allocation sequence in each included trial in sufficient detail to allow an assessment of whether it should produce comparable groups.

We will assess the method as:

- low risk (any truly random process, e.g. random number table, computer random number generator);

- high risk (any non-random process, e.g. odd or even date of birth; hospital or clinic record number);

- unclear (if the trial was described as randomised but the method used for the allocation sequence generation was not described).

\section{Allocation concealment (checking for possible selection bias)}

We will describe the method used to conceal the allocation sequence in each included trial in sufficient detail to determine whether intervention allocation could have been foreseen, in advance of or during recruitment, or changed after assignment.

We will assess the methods as:

- low risk (e.g. telephone or central randomisation, consecutively numbered sealed opaque envelopes);

- high risk (open random allocation, unsealed or non-opaque envelopes, alternation, date of birth);

- unclear (if the trial was described as randomised but the method used to conceal the allocation was not described).

\section{Blinding or masking (checking for possible performance bias)}

For each included study we will describe the methods used, if any, to blind trial participants and personnel from knowledge of which intervention a participant received. We will judge trials at low risk of bias if they were blinded, or if we judged that the lack of blinding did 
not affect the results. We will assess blinding separately for different outcomes or classes of outcomes.

We will assess the methods as:

- low risk, high risk, or unclear for participants;

- low risk, high risk, or unclear for personnel;

- low risk, high risk, or unclear for outcome assessors.

\section{Incomplete outcome data (checking for possible attrition bias} through withdrawals, dropouts, protocol deviations)

- Low risk (any one of the following): no missing outcome data; reasons for missing outcome data unlikely to be related to true outcome (for survival data, censoring unlikely to be introducing bias); missing outcome data balanced in numbers across intervention groups, with similar reasons for missing data across groups; for dichotomous outcome data, the proportion of missing outcomes compared with observed event risk not enough to have a clinically relevant impact on the intervention effect estimate; for continuous outcome data, plausible effect size (difference in means or standardised difference in means) among missing outcomes not enough to have a clinically relevant impact on observed effect size; missing data have been imputed using appropriate methods.

- High risk (any one of the following): reason for missing outcome data likely to be related to true outcome, with either imbalance in numbers or reasons for missing data across intervention groups; for dichotomous outcome data, the proportion of missing outcomes compared with observed event risk enough to induce clinically relevant bias in intervention effect estimate; for continuous outcome data, plausible effect size (difference in means or standardised difference in means) among missing outcomes enough to induce clinically relevant bias in observed effect size; 'as-treated' analysis done with substantial departure of the intervention received from that assigned at randomisation; potentially inappropriate application of simple imputation.

- Unclear risk (any one of the following): insufficient reporting of attrition or exclusions to permit judgement of 'low risk' or 'high risk' (e.g. number randomised not stated, no reasons for missing data provided); the study did not address this outcome.

\section{Selective reporting bias (reporting bias due to selective outcome reporting)}

We will describe for each included trial how we investigated the possibility of selective outcome reporting bias and what we found.

We will assess the methods as follows.

- Low risk (any one of the following): the trial protocol is available and all of the trial's pre-specified (primary and secondary) outcomes that are of interest in the review have been reported in the pre-specified way, or the trial protocol is not available but it is clear that the published reports include all expected outcomes, including those that were pre-specified (convincing text of this nature may be uncommon).

- High risk (any one of the following): not all of the trial's prespecified primary outcomes have been reported; one or more primary outcomes is reported using measurements, analysis methods or subsets of the data (e.g. subscales) that were not pre-specified; one or more reported primary outcomes were not pre-specified (unless clear justification for their reporting is provided, such as an unexpected adverse effect); one or more outcomes of interest in the review are reported incompletely so that they cannot be entered in a meta-analysis; the trial report fails to include results for a key outcome that would be expected to have been reported for such a trial.

- Unclear: insufficient information to permit judgement of 'low risk' or 'high risk'.

\section{Other bias (bias due to problems not covered elsewhere in the table)}

We will describe for each included trial any important concerns we have about other possible sources of bias (baseline imbalance, sponsorship bias, confirmation bias, bias of the presentation data, etc.).

- low risk of bias, the trial appears to be free of other components that could put it at risk of bias;

- unclear, the trial may or may not be free of other components that could put it at risk of bias;

- high risk of bias, there are other factors in the trial that could put it at risk of bias, e.g. no sample size calculation made.

\section{Overall risk of bias}

We will make explicit judgements about whether trials were at high risk of bias, according to the criteria given in the Cochrane Handbook for Systematic Reviews of Interventions (Higgins 2011). We will assess the likely magnitude and direction of bias, and whether we will consider it likely to impact our findings.

We will regard trials assessed as having a 'low risk of bias' in all of the individually-specified domains above as 'trials with an overall low risk of bias'. We will consider trials assessed as having an 'uncertain risk of bias' or a 'high risk of bias' in one or more of the above-specified individual domains as trials with 'an overall high risk of bias'.

\section{Measures of treatment effect}

For future updates, if we are able to include trials, we will perform meta-analyses according to Cochrane recommendations (Higgins 2011). We will use Review Manager 5 to analyse the data (RevMan 2014).

For binary outcomes, such as all-cause mortality, lack of improvement, and adverse events, we will calculate the risk ratio (RR) with the corresponding 95\% confidence intervals $(\mathrm{Cl})$.

For continuous outcomes, such as quality of life, and relief of fatigue, the authors will calculate the mean difference (MD) with the corresponding $95 \% \mathrm{Cl}$. However, if these outcomes are measured using different scales the authors plan to use the standardized mean difference (SMD) with the corresponding 95\% $\mathrm{Cl}$.

\section{Unit of analysis issues}

For future updates, if we are able to include trials, we will use the randomised SCD participant as the unit of analysis.

We do not regard cross-over trials or cluster randomised trials to be suitable designs for this intervention. 


\section{Dealing with missing data}

For future updates, if we are able to include trials, we will contact the lead author of each trial in an attempt to obtain the relevant information or missing data (or both). If no further information is available, we will carry out an available case analysis as our main analysis, that is, the denominator for each outcome in each trial will be the number randomised minus the number of participants whose outcomes were known to be missing.

We will assess the percentage of dropouts for each included trial, and for each trial group, and evaluate whether an intention-to-treat (ITT) analysis has been performed or could have been performed from the available published information.

\section{Intention-to-treat analyses}

Regarding the primary outcomes, we will include participants with incomplete or missing data in sensitivity analyses by imputing them according to the following scenarios (Hollis 1999).

- Poor-outcome analysis: assuming that dropouts or participants lost from both the experimental and the control arms experienced the outcome, including all randomised participants in the denominator.

- Good-outcome analysis: assuming that none of the dropouts or participants lost from the experimental and the control arms experienced the outcome, including all randomised participants in the denominator.

- Extreme-case analysis favouring the experimental intervention ('best-worse' case scenario): none of the dropouts or participants lost from the experimental arm, but all of the dropouts or participants lost from the control arm experienced the outcome, including all randomised participants in the denominator.

- Extreme-case analysis favouring the control ('worst-best' case scenario): all dropouts or participants lost from the experimental arm, but none from the control arm experienced the outcome, including all randomised participants in the denominator.

\section{Assessment of heterogeneity}

For future updates, if we are able to include trials, we will visually assess the forest plot for heterogeneity and use the $\mathrm{I}^{2}$ statistic and the $Q$ test $(P<0.1)$ to measure statistical heterogeneity between the trials. The $I^{2}$ statistic describes the percentage of total variation between trials due to heterogeneity rather than sampling error (Higgins 2003). We will consider there to be significant heterogeneity if $\mathrm{I}^{2}$ is more than $50 \%$ (Higgins 2011).

\section{Assessment of reporting biases}

For future updates, if we are able to include trials, if 10 or more trials are available, we will assess publication bias and other biases by the use of a funnel plot (Sterne 2011).

\section{Data synthesis}

For future updates, if we are able to include trials, we plan to conduct separate meta-analyses for the intervention groups (nonpharmaceutical interventions and pharmaceutical interventions).

If the eligible trials are sufficiently comparable in their clinical characteristics, we will use a random-effects model and a fixed- effect model meta-analysis. If there is discrepancy between the two models (e.g. one giving a significant intervention effect, the other no significant intervention effect) we will report both results; otherwise, we will report only the data using the random-effects model.

\section{Subgroup analysis and investigation of heterogeneity}

If we identify significant heterogeneity in a future update and we are able to include at least 10 trials in the meta-analysis, we will investigate the possible causes. We will devote further research to identify the possible causes for this heterogeneity, exploring the condition of the individuals.

We anticipate possible clinical heterogeneity in the effect of the intervention and if we find this we plan to conduct the following subgroup analyses if possible:

- HbSS type versus HbSC type;

- geographical location of RCT;

- participants' age: less than 18 years old compared to 18 years old and older;

- type of pharmaceutical intervention.

We will only conduct these subgroup analyses for primary outcomes.

\section{Sensitivity analysis}

For any future update, if we include 10 or more trials, we plan to conduct sensitivity analyses including only trials with an 'overall low risk of bias' (Higgins 2011). It is unlikely we will find many trials with an overall low risk of bias, therefore, we plan to choose three core domains: generation of allocation sequence; incomplete outcome data; and selective reporting bias.

\section{Trial sequential analysis}

Meta-analysis of cumulative data may run the risk of random errors ('play of chance') due to sparse data and repetitive analyses of the same data (Brok 2008; Brok 2009; Thorlund 2010; Thorlund 2011; Wetterslev 2008; Wetterslev 2009; Wetterslev 2017). In order to assess the risks of random errors in our cumulative meta-analyses, we will conduct diversity-adjusted trial sequential analyses based upon the proportion with the outcome in the control group; an $a$ priori set relative risk reduction of 20\%; an alpha of 5\%, an beta of $20 \%$; and the squared diversity in the meta-analysis (Thorlund 2009; Thorlund 2011; CTU 2011). For any future update, we will conduct sensitivity analysis of the trial sequential analysis to estimate the need for further trials.

\section{Summary of findings tables}

If, in the future, trials are identified and included in the review, we plan to use the principles of the GRADE system to assess the quality of the body of evidence associated with specific outcomes where possible (all-cause mortality, lack of improvement, quality of life, and adverse events) (Guyatt 2011a). We will construct a 'Summary of Findings (SoF) table' using the GRADE software (GRADEPro 2008). The GRADE approach appraises the quality of a body of evidence based on the extent to which one can be confident that an estimate of effect or association reflects the item being assessed. The quality of a body of evidence is considered to be: within-study risk of bias (methodologic quality); the directness of the evidence; heterogeneity of the data; precision of effect estimates; and risk of 
publication bias (Balshem 2011; Guyatt 2011b; Guyatt 2011c; Guyatt 2011d; Guyatt 2011e; Guyatt 2011f; Guyatt 2011g; Guyatt 2011h; Guyatt 2011i; Guyatt 2012).

\section{RESULTS}

\section{Description of studies}

\section{Results of the search}

In this updated review, we have not identified any potentiallyrelevant references through searches on interventions for treating intrahepatic cholestasis in people with SCD.

\section{Risk of bias in included studies}

We have included no trials in this review.

\section{Effects of interventions}

We have not identified any RCTs eligible for inclusion in this Cochrane Review (nor any that were potentially eligible), nor were we able to identify any ongoing trials.

\section{DISCUSSION}

\section{Summary of main results}

For this update, we have been unable to identify any RCTs addressing the benefits and harms of either non-pharmaceutical (simple red blood cell transfusion, exchange transfusion and liver transplantation) or pharmaceutical interventions (for treating cholestasis-associated pruritus: bile acid-binding resins (i.e. cholestyramine, colestipol); rifampin; opiate antagonists (naltrexone and nalmefene); sertraline; dexamethasone; guar gum; and activated charcoal for treating intrahepatic cholestasis in people with SCD.

\section{Overall completeness and applicability of evidence}

SCD is a major public health problem (WHO 2006; Modell 2008) with an estimated $70 \%$ of those affected living in Africa (Tluway 2017), the lack of RCTs to assess the clinical benefits and harms of the interventions for treating intrahepatic cholestasis in people with SCD is perplexing. In 2005, Lottenberg stated "The application of evidence-based medicine to the management of adults with sickle cell disease is currently primarily driven by clinical expertise and patient preference, as there is a paucity of randomized controlled trial data to guide decision-making" (Lottenberg 2005). This updated Cochrane Review provides strong evidence in support of Lottenberg's words.

SCD is a vasculopathy (Kassim 2013; Kato 2009). There are several studies reporting the findings of the molecular biology for explaining the endothelial damage in SCD (Caboot 2014; Goodman 2013; Gutsaeva 2014; Kato 2006; Kato 2008; Kato 2009; Kato 2014; Lockwood 2014; Morris 2014; Nishank 2013; Patel 2014; Sun 2013; Thakur 2014; Zhang 2012). They could explain the severe complications of these people and could be used as mechanistic reasoning for supporting RCTs in this condition. Certainly, the scientific uncertainty is undeniable. It is widely known that clinicians make practical decisions, often on the basis of inadequate information. Decisions on treatment should be taken based on the results of RCTs (Alderson 2004; Chalmers 2004).
The rationale for using either non-pharmaceutical or pharmaceutical treatments for intrahepatic cholestasis in SCD remains unknown. RCTs to answer the research question of this Cochrane Review have not yet been carried out. It is possible that some trials have been conducted, but due to their negative results, they remain unpublished (Easterbrook 1991; Gluud 1998). We can not support or rule out that trials on this subject are unpublished, which is not surprising as was recently highlighted (Glasziou 2017). This causes publication bias, reducing the possibility of developing valid systematic reviews (Diringer 2003). This is influenced by a number of factors, from the prevalence of the conditions to the resources available to undertake research. Keeping clinical uncertainty hidden does not benefit patients and may increase health-service costs (Alderson 2000). Conversely, admitting clinical uncertainty helps clarify treatment options and encourages further research (Alderson 2000; Diringer 2003).

We have concluded that intrahepatic cholestasis is a neglected complication of SCD. The paucity of data on clinical benefits and harms of treatments for intrahepatic cholestasis in SCD should stimulate the development of well-planned RCTs. Recently, a number of recommendations have been suggested in order to increase the value of and to reduce waste in biomedical research (Chalmers 2014; Macleod 2014).

\section{Quality of the evidence}

We did not identify any eligible RCTs.

\section{Potential biases in the review process}

While performing this systematic review, we also planned to look for 'significance-chasing biases' (Ioannidis 2010) which include, among others, publication bias, selective outcome reporting bias, selective analysis reporting bias, and fabrication bias (loannidis 2010). Publication bias represents a major threat to the validity of systematic reviews, particularly in reviews that include small trials. However, this Cochrane Review contains no trials and as such, no risk of bias could be evaluated. Trials with 'negative' results may have remained unpublished as suppression of information on specific outcomes may have occurred (Ioannidis 2010). We have been unable to identify evidence from RCTs supporting the use of any intervention either non-pharmaceutical or pharmaceutical for intrahepatic cholestasis in SCD.

The main limitation of this Cochrane Review is the paucity of evidence in people with SCD suffering from intrahepatic cholestasis.

\section{Agreements and disagreements with other studies or reviews}

There are no other reviews or studies to compare with this Cochrane Review.

\section{AUTHORS' CONCLUSIONS}

\section{Implications for practice}

We have not identified any randomised controlled trials (RCTs) of non-pharmaceutical interventions (simple red blood cell transfusion, exchange transfusion and liver transplantation) or pharmaceutical interventions (bile acid-binding resins (i.e. cholestyramine, colestipol); rifampin; opiate antagonists 
(naltrexone and nalmefene); sertraline; dexamethasone; guar gum; and activated charcoal) for treating intrahepatic cholestasis in sickle cell disease (SCD). Therefore, it is not possible to determine whether any of those interventions are beneficial or harmful for people with SCD and intrahepatic cholestasis. Accordingly, we are unable to evaluate the effects of any intervention for treating intrahepatic cholestasis in SCD.

\section{Implications for research}

Through this updated Cochrane Review, we have identified the need for well-designed, adequately powered RCTs to assess the benefits and harms of non-pharmaceutical and pharmaceutical treatments as a way of treating the intrahepatic cholestasis affecting people with SCD. Potential trials should assess clinical outcomes such as all-cause mortality, health-related quality of life, fatigue and adverse events. However, this is a relatively rare complication of SCD, making it unlikely that there would be enough participants to conduct such a trial in a reasonable time-frame.
RCTs should be reported according to the consolidated standards of reporting trials (CONSORT) statement for improving the quality of reporting of efficacy and harms in clinical research (Ioannidis 2004; Moher 2010; Turner 2012). Future trials should be planned following the Standard Protocol Items: Recommendations for Interventional Trials (SPIRIT) (Chan 2013; Chan 2013a) and the Foundation of Patient-Centered Outcomes Research recommendations (Basch 2012; Gabriel 2012; PCORI 2012).

\section{ACKNOWLEDGEMENTS}

We want to express our gratitude to Cystic Fibrosis and Genetic Disorders Group and peer reviewers for improving the quality of this Cochrane Review.

This project was supported by the National Institute for Health Research, via Cochrane Infrastructure funding to the Cochrane Cystic Fibrosis and Genetic Disorders Group. The views and opinions expressed therein are those of the authors and do not necessarily reflect those of the Systematic Reviews Programme, NIHR, NHS or the Department of Health. 


\section{REFERE N C E S}

\section{Additional references}

\section{Akinsheye 2010}

Akinsheye I, Klings ES. Sickle cell anemia and vascular dysfunction: the nitric oxide connection. Journal of Cellular Physiology 2010;224(3):620-5. [PMID: 20578237]

\section{Alderson 2000}

Alderson P, Roberts I. Should journals publish systematic reviews that find no evidence to guide practice? Examples from injury research. BMJ 2000;320:376-7. [PMID: 10657341]

\section{Alderson 2004}

Alderson P. Absence of evidence is not evidence of absence. British Medical Journal 2004;328:476-7. [PMID: 14988165]

\section{Angulo 2000}

Angulo P, Patel T, Jorgensen RA, Therneau TM, Lindor KD. Silymarin in the treatment of patients with primary biliary cirrhosis with a suboptimal response to ursodeoxycholic acid. Hepatology 2000;32(5):897-900. [PMID: 11050036]

\section{Azar 2017}

Azar S, Wong TE. Sickle cell disease: a brief update. The Medical Clinics of North America 2017;101(2):375-93. [PMID: 28189177]

\section{Azzaroli 2011}

Azzaroli F, Turco L, Lisotti A, Calvanese C, Mazzella G. The pharmacological management of intrahepatic cholestasis of pregnancy. Current Clinical Pharmacology 2011;6(1):12-7. [PMID: 21352094]

\section{Baichi 2005}

Baichi MM, Arifuddin RM, Mantry PS, Bozorgzadeh A, Ryan C. Liver transplantation in sickle cell anemia: a case of acute sickle cell intrahepatic cholestasis and a case of sclerosing cholangitis. Transplantation 2005;80(11):1630-2. [PMID: 16371935]

\section{Ballas 2012}

Ballas SK, Kesen MR, Goldberg MF, Lutty GA, Dampier C, Osunkwo I, et al. Beyond the definitions of the phenotypic complications of sickle cell disease: an update on management. The Scientific World Journal 2012;2012:949535. [PMID: 22924029]

\section{Balshem 2011}

Balshem H, Helfand M, Schunemann HJ, Oxman AD, Kunz R, Brozek J, et al. GRADE guidelines: 3. Rating the quality of evidence. Journal of Clinical Epidemiology 2011;64(4):401-6. [PMID: 21208779]

\section{Basch 2012}

Basch E, Aronson N, Berg A, Flum D, Gabriel S, Goodman SN, et al. Methodological standards and patient-centeredness in comparative effectiveness research: the PCORI perspective. JAMA 2012;307(15):1636-40. [PMID: 22511692]

\section{Brok 2008}

Brok J, Thorlund K, Gluud C, Wetterslev J. Trial sequential analysis reveals insufficient information size and potentially false positive results in many meta-analyses. Journal of Clinical Epidemiology 2008;61(8):763-9. [PMID: 18411040]

\section{Brok 2009}

Brok J, Thorlund K, Wetterslev J, Gluud C. Apparently conclusive meta-analyses may be inconclusive--Trial sequential analysis adjustment of random error risk due to repetitive testing of accumulating data in apparently conclusive neonatal meta-analyses. International Journal of Epidemiology 2009;38(1):287-98. [PMID: 18824466]

\section{Brunetta 2011}

Brunetta DM, Silva-Pinto AC, do Carmo Favarin de Macedo M, Bassi SC, Piccolo Feliciano JV, Ribeiro FB, et al. Intrahepatic cholestasis in sickle cell disease: a case report. Anemia 2011;2011:975731. [PMID: 21490769]

\section{Caboot 2014}

Caboot JB, Allen JL. Hypoxemia in sickle cell disease: significance and management. Paediatric Respiratory Reviews 2014;15(1):17-23. [PMID: 24461342]

\section{Carey 2012}

Carey EJ, Lindor KD. Current pharmacotherapy for cholestatic liver disease. Expert Opinion on Pharmacotherapy 2012;13(17):2473-84. [PMID: 23094715]

\section{Chalmers 2004}

Chalmers I. Well informed uncertainties about the effects of treatments. How clinicians and patients respond? BMJ 2004;328:475-6. [PMID: 14988164]

\section{Chalmers 2014}

Chalmers I, Bracken MB, Djulbegovic B, Garattini S, Grant J, Gülmezoglu AM, et al. How to increase value and reduce waste when research priorities are set. Lancet 2014;383(9912):156-65. [PMID: 24411644]

\section{Chan 2013}

Chan AW, Tetzlaff JM, Gotzsche PC, Altman DG, Mann H, Berlin JA, et al. SPIRIT 2013 explanation and elaboration: guidance for protocols of clinical trials. BMJ 2013;346:e7586. [PMID: 23303884]

\section{Chan 2013a}

Chan AW, Tetzlaff JM, Altman DG, Laupacis A, Gotzsche PC, Krleza-Jeric K, et al. SPIRIT 2013 statement: defining standard protocol items for clinical trials. Annals of Internal Medicine 2013;158(3):200-7. [PMID: 23295957]

\section{Chitturi 2002}

Chitturi S, George J, Ranjitkumar S, Kench J, Benson W. Exchange transfusion for severe intrahepatic cholestasis associated with sickle cell disease? Journal of Clinical Gastroenterology 2002;35(4):362-3. [PMID: 12352306] 


\section{Costa 2006}

Costa DB, Miksad RA, Buff MS, Wang Y, Dezube BJ. Case of fatal sickle cell intrahepatic cholestasis despite use of exchange transfusion in an African-American patient. Journal of the National Medical Association 2006;98(7):1183-7. [PMID: 16895293]

\section{Creary 2007}

Creary M, Williamson D, Kulkarni R. Sickle cell disease: current activities, public health implications, and future directions. Journal of Women's Health 2007;16:575-82. [PMID: 17627395]

\section{CTU 2011}

TSA - Trial Sequential Analysis. Copenhagen Trial Unit, Center for Clinical Intervention Research. http://ctu.dk/tsa/ (accessed 29 September 2011).

\section{Danielson 2002}

Danielson CF. The role of red blood cell exchange transfusion in the treatment and prevention of complications of sickle cell disease. Therapeutic Apheresis 2002;6(1):24-31. [PMID: 11886573]

\section{Delis 2006}

Delis SG, Touloumis Z, Bourli A, Madariaga J, Dervenis C. Can exchange transfusions treat postoperative intrahepatic colestasis in patients with sickle cell anemia? Transplantation Proceedings 2006;38(5):1385-6. [PMID: 16797311]

\section{Diringer 2003}

Diringer MN. Evidence-based medicine: what do you do when there's no evidence? Critical Care Medicine 2003;31(2):659-60. [PMID: 12576991]

\section{Donghaile 2013}

Donghaile DO, Klein HG. Hemapheresis. In: Hoffman R, Benz EJ, Silberstein LE, Heslop HE, Weitz JI, Anastasi J, editors(s). Hematology: Basic Principles and Practice. 6th edition. Philadelphia: Saunders, 2013:1716-26. [ISBN: 978-1-4377-2928-3]

\section{Easterbrook 1991}

Easterbrook PJ, Berlin J, Gopalan R, Matthews DR. Publication bias in clinical research. Lancet 1991;337:867-72. [PMID: 1672966]

\section{Ebert 2010}

Ebert EC, Nagar M, Hagspiel KD. Gastrointestinal and hepatic complications of sickle cell disease. Clinical Gastroenterology and Hepatology 2010;8(6):483-9; quiz e70. [PMID: 20215064]

\section{Emre 2000}

Emre S, Kitibayashi K, Schwartz ME, Ahn J, Birnbaum A, Thung SN, et al. Liver transplantation in a patient with acute liver failure due to sickle cell intrahepatic cholestasis. Transplantation 2000;69(4):675-6. [PMID: 10708131]

\section{Gabriel 2012}

Gabriel SE, Normand SL. Getting the Methods Right - The Foundation of Patient-Centered Outcomes Research. New
England Journal of Medicine 2012;367(9):787-90. [PMID: 22830434]

\section{Gardner 2014}

Gardner K, Suddle A, Kane P, O'Grady J, Heaton N, Bomford A, et al. How we treat sickle hepatopathy and liver transplantation in adults. Blood 2014;123(15):2302-7. [PMID: 24565828]

\section{Geenes 2009}

Geenes V, Williamson C. Intrahepatic cholestasis of pregnancy. World Journal of Gastroenterology 2009;15(17):2049-66. [PMID: 19418576]

\section{Glasziou 2017}

Glasziou P, Chalmers I. Can it really be true that 50\% of research is unpublished? http://blogs.bmj.com/ bmj/2017/06/05/paul-glasziou-and-iain-chalmers-canit-really-be-true-that-50-of-research-is-unpublished/? utm_campaign=shareaholic\&utm_medium=twitter\&utm_source=socialne (accessed 12 June 2017).

\section{Gluud 1998}

Gluud C. "Negative trials" are positive! Journal of Hepatology 1998;28(4):731-3. [PMID: 9566846]

\section{Goodman 2013}

Goodman SR, Daescu O, Kakhniashvili DG, Zivanic M. The proteomics and interactomics of human erythrocytes. Experimental Biology and Medicine 2013;238(5):509-18. [PMID: 23856902]

\section{GRADEPro 2008}

GRADE [Computer program]. Brozek J, Oxman A, Schünemann H. Version 3.6 for Windows 2008.

\section{Guimarães 2017}

Guimarães JA, Silva LCDS. Sickle cell intrahepatic cholestasis unresponsive to exchange blood transfusion: a case report. Revista Brasileira de Hematologia e Hemoterapia 2017;39(2):163-6. [PMID: 28577654]

\section{Gutsaeva 2014}

Gutsaeva DR, Montero-Huerta P, Parkerson JB, Yerigenahally SD, Ikuta T, Head CA. Molecular mechanisms underlying synergistic adhesion of sickle red blood cells by hypoxia and low nitric oxide bioavailability. Blood 2014;123(12):1917-26. [PMID: 24429338]

\section{Guyatt 2011a}

Guyatt GH, Oxman AD, Kunz R, Brozek J, Alonso-Coello P, Rind D, et al. GRADE guidelines 6 . Rating the quality of evidence--imprecision. Journal of Clinical Epidemiology 2011;64(12):1283-93. [PMID: 21839614]

\section{Guyatt 2011b}

Guyatt GH, Oxman AD, Kunz R, Woodcock J, Brozek J, Helfand M, et al. GRADE guidelines: 7. Rating the quality of evidence--inconsistency. Journal of Clinical Epidemiology 2011;64(12):1294-302. [PMID: 21803546] 


\section{Guyatt 2011c}

Guyatt GH, Oxman AD, Montori V, Vist G, Kunz R, Brozek J, et al. GRADE guidelines: 5 . Rating the quality of evidence--publication bias. Journal of Clinical Epidemiology 2011;64(12):1277-82. [PMID: 21802904]

\section{Guyatt 2011d}

Guyatt GH, Oxman AD, Kunz R, Woodcock J, Brozek J, Helfand M, et al. GRADE guidelines: 8 . Rating the quality of evidence--indirectness. Journal of Clinical Epidemiology 2011;64(12):1303-10. [PMID: 21802903]

\section{Guyatt 2011e}

Guyatt GH, Oxman AD, Sultan S, Glasziou P, Akl EA, AlonsoCoello P, et al. GRADE guidelines: 9. Rating up the quality of evidence. Journal of Clinical Epidemiology 2011;64(12):1311-6. [PMID: 21802902]

\section{Guyatt $2011 f$}

Guyatt GH, Oxman AD, Vist G, Kunz R, Brozek J, Alonso-Coello P, et al. GRADE guidelines: 4 . Rating the quality of evidence-study limitations (risk of bias). Journal of Clinical Epidemiology 2011;64(4):407-15. [PMID: 21247734]

\section{Guyatt 2011g}

Guyatt G, Oxman AD, Akl EA, Kunz R, Vist G, Brozek J, et al. GRADE guidelines: 1. Introduction-GRADE evidence profiles and summary of findings tables. Journal of Clinical Epidemiology 2011;64(4):383-94. [PMID: 21195583]

\section{Guyatt 2011h}

Guyatt GH, Oxman AD, Kunz R, Atkins D, Brozek J, Vist G, et al. GRADE guidelines: 2 . Framing the question and deciding on important outcomes. Journal of Clinical Epidemiology 2011;64(4):395-400. [PMID: 21194891]

\section{Guyatt 2011i}

Guyatt GH, Oxman AD, Schunemann HJ, Tugwell P, Knottnerus A. GRADE guidelines: a new series of articles in the Journal of Clinical Epidemiology. Journal of Clinical Epidemiology 2011;64(4):380-2. [PMID: 21185693]

\section{Guyatt 2012}

Guyatt G, Oxman AD, Sultan S, Brozek J, Glasziou P, AlonsoCoello $P$, et al. GRADE guidelines 11-making an overall rating of confidence in effect estimates for a single outcome and for all outcomes. Journal of Clinical Epidemiology 2012;66(2):151-157. [PMID: 22542023]

\section{Higgins 2003}

Higgins JP, Thompson SG, Deeks JJ, Altman DG. Measuring inconsistency in meta-analyses. British Medical Journal 2003;327(7414):557-60. [PMID: 12958120]

\section{Higgins 2011}

Higgins JP, Green S, editor(s). Cochrane Handbook for Systematic Reviews of Interventions Version 5.1.0 (updated March 2011). The Cochrane Collaboration, 2011. Available from handbook.cochrane.org.

\section{Hollis 1999}

Hollis S, Campbell F. What is meant by intention to treat analysis? Survey of published randomised controlled trials. British Medical Journal 1999;319(7211):670-4. [PMID: 10480822]

\section{Horn 1987}

Horn A, Freed N, Pecora AA. Sickle cell hepatopathy: diagnosis and treatment with exchange transfusion. Journal of the American Osteopathic Association 1987;87(2):130-3. [PMID: 3558021]

\section{ICH-GCP 1997}

International Conference on Harmonisation Expert Working Group. International conference on harmonisation of technical requirements for registration of pharmaceuticals for human use. ICH harmonised tripartite guideline. Guideline for good clinical practice 1997 CFR \& ICH Guidelines. Vol. 1. PA 19063-2043, USA: Barnett International/PAREXEL, 1997.

\section{loannidis 2004}

Ioannidis JP, Evans SJ, Gotzsche PC, O'Neill RT, Altman DG, Schulz K, et al. Better reporting of harms in randomized trials: an extension of the CONSORT statement. Annals of Internal Medicine 2004;141(10):781-8. [PMID: 15545678]

\section{loannidis 2010}

Ioannidis JP. The art of getting it wrong. Research Synthesis Methods 2010;1(3-4):169-84.

\section{Johnson 1985}

Johnson CS, Omata M, Tong MJ, Simmons JF Jr, Weiner J, Tatter D. Liver involvement in sickle cell disease. Medicine 1985;64(5):349-56. [PMID: 4033412]

\section{Kaplan 2012}

Kaplan A. Complications of apheresis. Seminars in Dialysis 2012;25(2):152-8. [PMID: 22321209]

\section{Karunatilake 2009}

Karunatilake $\mathrm{H}$, Vithiya $\mathrm{K}$, Malavan $\mathrm{R}$, Natalia $\mathrm{H}$, Ratnayake $\mathrm{H}$. Exchange transfusion for intrahepatic cholestasis due to sickle beta thalassaemia. Ceylon Medical Journal 2009;54(3):95-6. [PMID: 19999791]

\section{Kassim 2013}

Kassim AA, DeBaun MR. Sickle cell disease, vasculopathy, and therapeutics. Annual Review of Medicine 2013;64:451-66. [PMID: 23190149]

\section{Kato 2006}

Kato GJ, McGowan V, Machado RF, Little JA, Taylor J 6th, Morris CR, et al. Lactate dehydrogenase as a biomarker of hemolysis-associated nitric oxide resistance, priapism, leg ulceration, pulmonary hypertension, and death in patients with sickle cell disease. Blood 2006;107(6):2279-85. [PMID: 16291595]

\section{Kato 2007}

Kato GJ, Gladwin MT, Steinberg MH. Deconstructing sickle cell disease: reappraisal of the role of hemolysis in the development of clinical subphenotypes. Blood Reviews 2007;21:37-47. [PMID: 17084951] 


\section{Kato 2008}

Kato GJ, Gladwin MT. Evolution of novel small-molecule therapeutics targeting sickle cell vasculopathy. JAMA 2008;300(22):2638-46. [PMID: 19066384]

\section{Kato 2009}

Kato GJ, Hebbel RP, Steinberg MH, Gladwin MT. Vasculopathy in sickle cell disease: Biology, pathophysiology, genetics, translational medicine, and new research directions. American Journal of Hematology 2009;84(9):618-25. [PMID: 19610078]

\section{Kato 2014}

Kato GJ. No NO means yes to sickle red cell adhesion. Blood 2014;123(12):1780-2. [PMID: 24652963]

\section{Khan 2011}

Khan MA, Kerner JA. Reversal of hepatic and renal failure from sickle cell intrahepatic cholestasis. Digestive Diseases and Sciences 2011;56(6):1634-6. [PMID: 21267779]

\section{Khurshid 2002}

Khurshid I, Anderson L, Downie GH, Pape GS. Sickle cell disease, extreme hyperbilirubinemia, and pericardial tamponade: case report and review of the literature. Critical Care Medicine 2002;30(10):2363-7. [PMID: 12394969]

\section{Kleinman 1984}

Kleinman SH, Hurvitz CG, Goldfinger D. Use of erythrocytapheresis in the treatment of patients with sickle cell anemia. Journal of Clinical Apheresis 1984;2(2):170-6. [PMID: 6543585]

\section{Kwun 2019}

Kwun Lui S, Krasinskas A, Shah R, Tracht JM. Orthotropic liver transplantation for acute intrahepatic cholestasis in sickle cell disease: clinical and histopathologic features of a rare case. International Journal of Surgical Pathology 2019;27(4):411-7. [PMID: 30198363]

\section{Lee 2012}

Lee G, Arepally GM. Anticoagulation techniques in apheresis: from heparin to citrate and beyond. Journal of Clinical Apheresis 2012;27(3):117-25. [PMID: 22532037]

\section{Likhtshteyn 2019}

Likhtshteyn M, Iqbal S, McFarlane SI, Thor S. Intrahepatic cholestasis in a sickle cell patient unresponsive to exchange blood transfusion. American Journal of Medical Case Reports 2019;7(4):67-70. [PMID: 31535002]

\section{Lockwood 2014}

Lockwood SY, Erkal JL, Spence DM. Endothelium-derived nitric oxide production is increased by ATP released from red blood cells incubated with hydroxyurea. Nitric Oxide 2014;38:1-7. [PMID: 24530476]

\section{Lottenberg 2005}

Lottenberg R, Hassell KL. An evidence-based approach to the treatment of adults with sickle cell disease. Hematology / The Education Program of the American Society of Hematology.
American Society of Hematology. Education Program 2005:58-65. [PMID: 16304360]

\section{Macleod 2014}

Macleod MR, Michie S, Roberts I, Dirnagl U, Chalmers I, loannidis JP, et al. Biomedical research: increasing value, reducing waste. Lancet 2014;383(9912):101-4. [PMID: 24411643]

\section{Maji 2020}

Maji P, Malik R, Lodha R, Bagga A. Sickle cell intrahepatic cholestasis with acute liver failure and acute kidney injury: favourable outcome with exchange transfusion. Indian Journal of Pediatrics 2020;87(1):83. [PMID: 31520310]

\section{Modell 2008}

Modell B, Darlison M. Global epidemiology of haemoglobin disorders and derived service indicators. Bulletin of the World Health Organization 2008;86:480-7. [PMID: 18568278]

\section{Moher 2010}

Moher D, Hopewell S, Schulz KF, Montori V, Gotzsche PC, Devereaux PJ, et al. CONSORT 2010 Explanation and Elaboration: Updated guidelines for reporting parallel group randomised trials. Journal of Clinical Epidemiology 2010;63(8):e1-37. [PMID: 20346624]

\section{Morris 2008}

Morris CR. Mechanisms of vasculopathy in sickle cell disease and thalassemia. Hematology / the Education Program of the American Society of Hematology. American Society of Hematology. Education Program 2008;(1):177-85. [PMID: 19074078]

\section{Morris 2014}

Morris CR. Alterations of the arginine metabolome in sickle cell disease: a growing rationale for arginine therapy. Hematology/ Oncology Clinics of North America 2014;28(2):301-21. [PMID: 24589268]

\section{Muriel 2008}

Muriel P, Rivera-Espinoza Y. Beneficial drugs for liver diseases. Journal of Applied Toxicology 2008;28(2):93-103. [PMID: 17966118]

\section{NACB 2000}

Dufour DR (editor). The National Academy of Clinical Biochemistry. Laboratory guidelines for screening, diagnosing and monitoring for hepatic injury. Laboratory Medicine Practice Guidelines 2000;12:1-61.

\section{Nishank 2013}

Nishank SS, Singh MP, Yadav R, Gupta RB, Gadge VS, Gwal A. Endothelial nitric oxide synthase gene polymorphism is associated with sickle cell disease patients in India. Journal of Human Genetics 2013;58(12):775-9. [PMID: 24088668]

\section{Omata 1986}

Omata M, Johnson CS, Tong M, Tatter D. Pathological spectrum of liver diseases in sickle cell disease. Digestive Diseases and Sciences 1986;31(3):247-56. [PMID: 3948629] 


\section{Patel 2014}

Patel DK, Mohapatra MK, Thomas AG, Patel S, Purohit P. Procalcitonin as a biomarker of bacterial infection in sickle cell vaso-occlusive crisis. Mediterranean Journal of Hematology and Infectious Diseases 2014;6(1):e2014018. [PMID: 24678395]

\section{PCORI 2012}

Patient-Centered Outcomes Research Institute (PCORI). Preliminary draft methodology report: "Our questions, our decisions: Standards for patient-centered outcomes research". http://www.pcori.org/assets/Preliminary-Draft-MethodologyReport.pdf (accessed 07 July 2014):1-61.

\section{Pecker 2018}

Pecker LH, Patel N, Creary S, Darbari A, Meier ER, Darbari DS, et al. Diverse manifestations of acute sickle cell hepatopathy in pediatric patients with sickle cell disease: A case series. Pediatric Blood \& Cancer 2018;65(8):e27060. [PMID: 29667721]

\section{Piel 2017}

Piel FB, Steinberg MH, Rees DC. Sickle cell disease. The New England Journal of Medicine 2017;376(16):1561-73. [PMID: 28423290]

\section{Racho 2019}

Racho RG, Krishna M, Canabal JM, Keaveny AP. Liver transplantation for acute liver failure secondary to acute sickle intrahepatic cholestasis. The American Journal of Gastroenterology 2019;Jul 31:[Epub ahead of print]. [PMID: 31365350]

\section{RevMan 2014 [Computer program]}

Version 5.3. Copenhagen: The Nordic Cochrane Centre: The Cochrane Collaboration Review Manager (RevMan). Version 5.3. Copenhagen: The Nordic Cochrane Centre: The Cochrane Collaboration, 2014.

\section{Sarode 2006}

Sarode R, Altuntas F. Blood bank issues associated with red cell exchanges in sickle cell disease. Journal of Clinical Apheresis 2006;21(4):271-3. [PMID: 17177280]

\section{Savafi 2006}

Savafi NA, Akbulut S, Koseoglu T, Albayrak L. Chronic liver disease in a patient with sickle cell anemia. Turkish Journal of Gastroenterology 2006;17(2):123-5. [PMID: 16830296]

\section{Sheehy 1980}

Sheehy TW, Law DE, Wade BH. Exchange transfusion for sickle cell intrahepatic cholestasis. Archives of Internal Medicine 1980;140(10):1364-6. [PMID: 7425771]

\section{Simon 2016}

Simon E, Long B, Koyfman A. Emergency medicine management of sickle cell disease complications: an evidence-based update. The Journal of Emergency Medicine 2016;51(4):370-81. [PMID: 27553919]

\section{Steinberg 2009}

Steinberg MH. Genetic etiologies for phenotypic diversity in sickle cell anemia. Scientific World Journal 2009;9:46-67. [PMID: 19151898]

\section{Sterne 2011}

Sterne JA, Sutton AJ, Ioannidis JP, Terrin N, Jones DR, Lau J, et al. Recommendations for examining and interpreting funnel plot asymmetry in meta-analyses of randomised controlled trials. British Medical Journal 2011;343:d4002. [PMID: 21784880]

\section{Sun 2013}

Sun K, Xia Y. New insights into sickle cell disease: a disease of hypoxia. Current Opinion in Hematology 2013;20(3):215-21. [PMID: 23549375]

\section{Swerdlow 2006}

Swerdlow PS. Red cell exchange in sickle cell disease. Hematology / the Education Program of the American Society of Hematology. American Society of Hematology. Education Program 2006:48-53. [PMID: 17124039]

\section{Thakur 2014}

Thakur TJ, Guindo A, Cullifer LR, Li Y, Imumorin IG, Diallo DA, et al. Endothelin-1 but not endothelial nitric oxide synthase gene polymorphism is associated with sickle cell disease in Africa. Gene Regulation and Systems Biology 2014;8:119-26. [PMID: 24932102]

\section{Theocharidou 2019}

Theocharidou E, Suddle AR. The liver in sickle cell disease. Clinics in Liver Disease 2019;23(2):177-89. [PMID: 30947870]

\section{Thorlund 2009}

Thorlund K, Devereaux PJ, Wetterslev J, Guyatt G, Ioannidis JP, Thabane $L$, et al. Can trial sequential monitoring boundaries reduce spurious inferences from meta-analyses? International Journal of Epidemiology 2009;38(1):276-86. [PMID: 18824467]

\section{Thorlund 2010}

Thorlund K, Anema A, Mills E. Interpreting meta-analysis according to the adequacy of sample size. An example using isoniazid chemoprophylaxis for tuberculosis in purified protein derivative negative HIV-infected individuals. Clinical Epidemiology 2010;2:57-66. [PMID: 20865104]

\section{Thorlund 2011}

Thorlund K, Engstrøm J, Wetterslev J, Brok J, Imberger G, Gluud C. User Manual for Trial Sequential Analysis (TSA). http:// ctu.dk/tsa/files/tsa_manual.pdf (accessed 30 April 2012).

\section{Tiftik 2004}

Tiftik N, Altintas E, Kiykim A, Ucbilek E, Sezgin O. Long-term red blood cell exchange can be used to successfully treat sickle cell intrahepatic cholestasis: a case report. Journal of Clinical Apheresis 2004;19(1):17-9. [PMID: 15095397]

\section{Tluway 2017}

Tluway F, Makani J. Sickle cell disease in Africa: an overview of the integrated approach to health, research, education 
and advocacy in Tanzania, 2004-2016. British Journal of Haematology 2017;177(6):919-29. [PMID: 28295224]

\section{Turner 2012}

Turner L, Shamseer L, Altman DG, Weeks L, Peters J, Kober T, et al. Consolidated standards of reporting trials (CONSORT) and the completeness of reporting of randomised controlled trials (RCTs) published in medical journals. Cochrane Database of Systematic Reviews 2012, Issue 11. [DOI: 10.1002/14651858.MR000030.pub2]

\section{Ware 2017}

Ware RE, de Montalembert M, Tshilolo L, Abboud MR. Sickle cell disease. Lancet 2017;Epub ahead of print. [PMID: 28159390]

\section{Weatherall 2006}

Weatherall D, Akinyanju O, Fucharoen S, Olivieri N, Musgrove P. Inherited Disorders of Hemoglobin. In: Disease Control Priorities in Developing Countries. 2nd edition. Washington DC: The World Bank and Oxford University Press, 2006.

\section{Wetterslev 2008}

Wetterslev J, Thorlund K, Brok J, Gluud C. Trial sequential analysis may establish when firm evidence is reached in cumulative meta-analysis. Journal of Clinical Epidemiology 2008;61(1):64-75. [PMID: 18083463]

\section{Wetterslev 2009}

Wetterslev J, Thorlund K, Brok J, Gluud C. Estimating required information size by quantifying diversity in random-effects model meta-analyses. BMC Medical Research Methodology 2009;9:86. [PMID: 20042080]

\section{A P P E N D I CES}

Appendix 1. Glossary of medical terms

\section{Wetterslev 2017}

Wetterslev J, Jakobsen JC, Gluud C. Trial Sequential Analysis in systematic reviews with meta-analysis. BMC Medical Research Methodology 2017;17(1):39. [PMID: 28264661]

\section{WHO 2006}

World Health Organization. 59th World Health Assembly resolution WHA59.20 on sickle cell anaemia. http:// apps.who.int/gb/ebwha/pdf_files/WHA59-REC1/e/Resolutionsen.pdf (accessed December 14, 2012):1-40.

\section{Zhang 2012}

Zhang Y, Xia Y. Adenosine signaling in normal and sickle erythrocytes and beyond. Microbes and Infection 2012;14(10):863-73. [PMID: 22634345]

\section{References to other published versions of this review Martí-Carvajal 2015}

Martí-Carvajal AJ, Simancas-Racines D. Interventions for treating intrahepatic cholestasis in people with sickle cell disease. Cochrane Database of Systematic Reviews 2015, Issue 3. [DOI: 10.1002/14651858.CD010985.pub2]

\section{Martí-Carvajal 2017}

Martí-Carvajal AJ, Martí-Amarista CE. Interventions for treating intrahepatic cholestasis in people with sickle cell disease. Cochrane Database of Systematic Reviews 2017, Issue 7. [DOI: 10.1002/14651858.CD010985.pub3]

\begin{tabular}{lll}
\hline Term & Definition & Source \\
\hline Acute hepatic injury & $\begin{array}{l}\text { Acute hepatic injury can be recognized by the presence of jaundice or non- } \\
\text { specific symptoms of acute illness accompanied } \\
\text { by elevation of aspartate aminotransferase (AST) or alanine aminotrans- } \\
\text { ferase (ALT) (or both) activities. }\end{array}$ & $\begin{array}{l}\text { NACB 2000 } \\
\text { (www.aasld.org/ } \\
\text { practiceguide- } \\
\text { lines/Documents/Prac- } \\
\end{array}$ \\
& tice\%20Guidelines/He- \\
& patic.pdf).
\end{tabular}

Albumin

Albumin is the most abundant plasma protein produced by hepatocytes. Rate of production is dependent on several factors, including supply of amino acids, plasma oncotic pressure, levels of inhibitory cytokines (particularly (L-6), and number of functioning hepatocytes.
NACB 2000 (www.aasld.org/ practiceguidelines/Documents/Practice\%20Guidelines/Hepatic.pdf)

NACB 2000 Aspartate aminotransferase (AST, also sometimes termed serum glutamic oxaloacetic transaminase (SGOT)) and alanine aminotransferase (ALT, also sometimes ferase termed serum glutamic pyruvate transaminase (SGPT)) are widely distributed in cells throughout the body. AST is found primarily in heart, liver, skeletal muscle, (www.aasld.org/ practiceguidelines/Documents/Practice\%20Guidelines/Hepatic.pdf) 


\section{Alkaline phosphatase} Alkaline phosphatase (ALP), involved in metabolite transport across cell
membranes, is found, in decreasing order of abundance, in placenta, ileal mucosa, kidney, bone, and liver. Bone, liver, and kidney alkaline phosphatase share a common protein structure, coded for by the same gene.
A disease characterized by chronic hemolytic anemia, episodic painful crises, and pathologic involvement of many organs. It is the clinical expression of homozygosity for hemoglobin S.

\author{
NACB 2000 \\ (www.aasld.org/ \\ practiceguide- \\ lines/Documents/Prac- \\ tice\%20Guidelines/He- \\ patic.pdf).
}

\section{MeSH (Medical Sub- ject Headings). Na- tional Library of Medi- cine (www.ncbi.nlm.ni- h.gov/mesh).}

NACB 2000

(www.aasld.org/ practiceguidelines/Documents/Practice\%20Guidelines/Hepatic.pdf) in cells throughout the body. AST is found primarily in heart, liver, skeletal muscle, and kidney, while ALT is found primarily in liver and kidney, with lesser amounts in heart and skeletal muscle.

\section{Bilirubin}

Daily production of unconjugated bilirubin is $250 \mathrm{mg}$ to $350 \mathrm{mg}$, mainly from senescent erythrocytes (65). Clearance at normal values is $5 \mathrm{mg} / \mathrm{kg} / \mathrm{day}$, or about $400 \mathrm{mg} /$ day in adults; the rate does not increase significantly with hemolysis (66). The half-life of unconjugated bilirubin is $<5$ minutes (67). UDPglucuronyltransferase catalyzes rapid conjugation of bilirubin in the liver; conjugated bilirubin is excreted into bile and is essentially absent from blood in normal individuals. Delta bilirubin (-bilirubin, also sometimes termed biliprotein) is produced by reaction of conjugated bilirubin with albumin (68); it has a half-life of about 17 to 20 days (the same as albumin), accounting for prolonged jaundice in patients recovering from hepatitis or obstruction.
NACB 2000

(www.aasld.org/ practiceguide-

lines/Documents/Practice\%20Guidelines/Hepatic.pdf)
Chronic hepatic injury is a relatively common disorder with minimal symptoms, yet with long term risk of significant morbidity and mortality. It is defined pathologically by ongoing hepatic necrosis and inflammation in the liver, often accompanied by fibrosis.
NACB 2000

(www.aasld.org/ practiceguidelines/Documents/Practice\%20Guidelines/Hepatic.pdf)

MeSH (Medical Subject Headings). National Library of Medicine (www.ncbi.nlm.nih.gov/mesh).

NACB 2000

(www.aasld.org/ practiceguide-

lines/Documents/Practice\%20Guidelines/Hepatic.pdf) suggesting impaired clearance.

One of the sickle cell disorders characterized by the presence of both hemoglobin $\mathrm{S}$ and hemoglobin C. It is similar to, but less severe than sickle cell anemia.
MeSH (Medical Subject Headings). National Library of Medicine (www.ncbi.nlm.nih.gov/mesh). 

Hemoglobin, sickle $\quad$ It is an abnormal hemoglobin due to point mutation (GAG $\rightarrow$ GTG) in exon 1 of the $\beta$ globin gene resulting in the substitution of glutamic acid by valine at position 6 of the $\beta$ globin polypeptide chain.

A condition characterized by an abnormal increase of bilirubin in the blood, which may result in jaundice. Bilirubin, a breakdown product of heme, is normally excreted in the bile or further catabolized before excretion in the urine.
MeSH (Medical Subject Headings). National Library of Medicine (www.ncbi.nlm.nih.gov/mesh).

MeSH (Medical Subject Headings). National Library of Medicine (www.ncbi.nlm.nih.gov/mesh).

\begin{tabular}{lll}
\hline $\begin{array}{l}\text { Prothrombin time } \\
\text { Prothrombin time (PT) measures the time required for plasma to clot after }\end{array}$ & $\begin{array}{l}\text { NACB } 2000 \\
\text { (www.aasld.org/ } \\
\text { addition of tissue factor and phospholipid; it is affected by changes in the ac- } \\
\text { tivity of factors X, VII, V, II (prothrombin) and I (fibrinogen). All of these factors } \\
\text { are synthesized in the liver, and three (II, VII, and X) are activated by a vitamin } \\
\text { K-dependent enzyme through addition of a second, -carboxyl group on glu- } \\
\text { tamic acid residues. }\end{array}$ & $\begin{array}{l}\text { lines/Documents/Prac- } \\
\text { tice\%20Guidelines/He- } \\
\text { patic.pdf). }\end{array}$ \\
& The condition of being heterozygous for hemoglobin S. & $\begin{array}{l}\text { MeSH (medical sub- } \\
\text { ject headings). Na- } \\
\text { tional Library of Medi- } \\
\text { cine (www.ncbi.nlm.ni- } \\
\text { h.gov/mesh). }\end{array}$ \\
\end{tabular}

WHAT'S NEW

\begin{tabular}{lll}
\hline Date & Event & Description \\
\hline 25 November 2019 & New search has been performed & $\begin{array}{l}\text { A search of the Cochrane Cystic Fibrosis and Genetic Disorders } \\
\text { Group's Haemoglobinopathies Trials Register did not identify } \\
\text { any potentially-eligible trials. Further searching (LILACS, Epis- } \\
\text { temonikos, WHO International Clinical Trials Registry Platform } \\
\text { search portal and ClinicalTrials.gov) did not identify any poten- } \\
\text { tially-eligible trials. }\end{array}$ \\
& & $\begin{array}{l}\text { This updated Cochrane Review did not identify any randomised } \\
\text { controlled trials assessing interventions for treating intrahepatic } \\
\text { cholestasis in people with sickle cell disease. Minor changes have } \\
\text { been made throughout the review. }\end{array}$ \\
\hline have not changed & & \\
& &
\end{tabular}

\section{H IST ORY}

Protocol first published: Issue 2, 2014

Review first published: Issue 3, 2015 


\begin{tabular}{lll}
\hline Date & Event & Description \\
\hline 31 July 2017 & $\begin{array}{l}\text { New citation required but conclusions } \\
\text { have not changed }\end{array}$ & Minor changes have been made throughout the review. \\
\hline 31 July 2017 & New search has been performed & $\begin{array}{l}\text { A search of the Cochrane Cystic Fibrosis and Genetic Disorders } \\
\text { Group's Haemoglobinopathies Trials Register did not identify } \\
\text { any potentially-relevant trials for inclusion in this review. Further } \\
\text { searches of LILACS, Epistemonikos, WHO International Clinical } \\
\text { Trials Registry Platform Search Portal and ClinicalTrials.gov also } \\
\text { did not identify any eligible trials. }\end{array}$ \\
\hline
\end{tabular}

\section{CONTRIBUTIONS OF AUTHORS}

Arturo Martí-Carvajal conceived the review question, developed and coordinated the review, completed the first draft of the review, approved the final version of the review prior to submission.

Cristina Martí-Amarista: approved the final version of the review prior to submission and is guarantor for the review.

\section{DECLARATIONSOF INTEREST}

Arturo Martí-Carvajal: none known.

Cristina Martí-Amarista: none known.

\section{SOURCES OF SUPPORT}

\section{Internal sources}

- No sources of support supplied

\section{External sources}

- Iberoamerican Cochrane Center, Spain

Academic.

- National Institute for Health Research, UK

This systematic review was supported by the National Institute for Health Research, via Cochrane Infrastructure funding to the Cochrane Cystic Fibrosis and Genetic Disorders Group.

\section{DIFFERENCES BETWEEN PROTOCOLANDREVIEW}

Based on two suggestions made by a peer reviewer and approved by editorial base, we did two changes:

1. To remove hydroxyurea as potential pharmacological intervention for treating intrahepatic cholestasis in SCD.

2. We included platelet count as secondary outcome. Therefore, we amended the 'Measures of treatment effect' section: "For continuous outcomes, such as quality of life, and relief of fatigue, the authors will calculate standardized mean difference (SMD) with the corresponding $95 \% \mathrm{Cl}$, if those outcomes are measured with different scales. On the contrary, either platelet count or quality of life, and relief of fatigue we plan to calculate mean difference (MD) with the corresponding $95 \% \mathrm{Cl}$ ".

We were unable to search on African Index Medicus (//indexmedicus.afro.who.int/). This web site displayed the following message "Access Denied (license_expired). A license has expired on the Proxy, and your request is not permitted: "The SGOS license has expired". For assistance, contact your network support team." (Accessed: 23 May 2017).

\section{IN DEX TERMS}

\section{Medical Subject Headings (MeSH)}

Anemia, Sickle Cell [* ${ }^{\star}$ complications]; Cholestasis, Intrahepatic [etiology] [therapy] 


\section{MeSH check words}

Humans 